\title{
AFRICAN SOLUTIONS TO AFRICA'S PROBLEMS? AFRICAN APPROACHES TO PEACE, SECURITY AND STABILITY
}

\author{
Hussein Solomon ${ }^{l}$ \\ University of the Free State
}

\begin{abstract}
Africa, with its combination of fragile governments and institutions, abject poverty amid great resources, wealth and a legacy of incessant violent conflict, has increasingly become integrated into the global security architecture. With growing globalisation, insecurity anywhere is a threat to security everywhere. Given this context, Africa's own insecurity is serving as a source of concern for the United States and other global powers. Africa is plagued by a broad spectrum of traditional and non-traditional security threats on the one hand, and yet, as will be seen in this article, home to an emerging regional and international security consciousness and activism on the other. It was the purpose of the study on which this article reports, to examine African approaches to ensure peace, security and stability on the continent at national, sub-regional and regional level. The African Union's (AU) approach to the promotion of peace and security on the continent can be described as a constructivist-inspired cooperative security approach, and it will be demonstrated that sub-regional organisations are very important security enforcing actors in the African security architecture.
\end{abstract}

\section{Introduction}

With its failed and failing states, its institutional weaknesses and attendant ungoverned spaces combined with increasing gaps between the 'haves' and 'havenots', conflict in Africa has increasingly become endemic. The continent's security, meanwhile, has become a rising source of concern for the United States and other global powers. The African security environment today is a dynamic one, characterised by a volatile mix of conflict, instability and state weakness, and

Scientia Militaria, South African Journal of Military Studies, Vol 43, No. 1, 2015, pp. 45-76. doi : $10.5787 / 43-1-1109$ analysts have attempted to offer a variety of perspectives to explain Africa's security dynamics since the end of the Cold War. ${ }^{2}$ Africa is plagued by a broad spectrum of 
traditional and non-traditional security threats whilst at the same time is home to an emerging regional and international security consciousness and activism.

Paradoxically, as much as Africa and its current problems are often rooted in the past, the continent today finds itself squarely at the forefront of new security thinking, and it has become a test bed for innovative approaches and strategies. The range of potential security threats on the continent are multiplying at frightening rates, and out of necessity, Africa's governments, people and institutions are being forced to reassess and rethink the very nature and meaning of security. Security for whom, and for what? The answers to these types of questions, which lie at the core of new security thinking, will undoubtedly require breaking away from historical and Western security constructs as the continent struggles to find its own path.

It was the purpose of the study reported here to examine African approaches to ensure peace, security and stability on the continent at national, sub-regional and regional level. The article starts by providing an analysis of the weak nature of the modern African state, which often serves as a catalyst for other security issues to manifest. The second part of the article is devoted to the emergent security culture that has been cultivated by Africa's foremost regional organisation in the promotion of security on the continent, the African Union (AU) (and its predecessor, the Organisation of African Unity, the OAU). The AU's approach to the promotion of peace and security on the continent can be described as a constructivist-inspired cooperative security approach ${ }^{3}$ and, although the exact separation of powers between the AU and Africa's sub-regional organisations is not clean-cut, it will be shown that sub-regional organisations are very important security enforcing actors in the African security architecture.

\section{Problematising the African state}

In recent years, far from being viewed as the 'hopeless continent', Africa is being characterised as 'hopeful' by publications such as The Economist. ${ }^{4}$ There seems to be some empirical evidence to support such an optimistic view. After all, half a dozen African economies have been growing at more than 6 per cent per year for the past six years, and two out of every three African countries hold elections. ${ }^{5}$ However, such optimism is seriously misplaced. While economic growth is taking place, such growth is occurring from a low base - reflected in the fact that Africa accounts for a dismal 2,5 per cent of the world output at purchasing-power parity despite accounting for a sixth of the world's population. ${ }^{6}$ Moreover, such economic growth is hardly sustainable given the income disparities on the continent - a sure 
recipe for further socio-political unrest. Consider here the following statistics from the African Development Bank: ${ }^{7}$

- 60 per cent of Africans are engaged in low-paid, unpredictable and informal jobs;

- half of Africa's population of one billion subsists on less than $\$ 1,25$ per day - the international poverty threshold; and

- $\quad$ only half of Africa's youth is economically active.

On the political front, while elections have been taking place on the continent, these have not necessarily led to liberal democracy. This is reflected in the fact that only 11 African countries have been classified as 'free' by Freedom House, while 23 have been classified as 'partly free' and 22 as 'not free'. ${ }^{8}$ In attempting to explain the discrepancy between holding elections and perpetuating authoritarian rule, Fareed Zakaria coined the phrase 'illiberal democracy'. He defined this as “... the troubling phenomenon of elected governments systematically abusing individual rights and depriving people of liberty".

This volatile mix of economic disparities and a democratic deficit has provided the ideal recipe for sustained conflict within African polities, laying the seeds of state failure or state collapse. Indeed, in the latest Failed State Index issued by the US-based Fund for Peace, the top five positions are all occupied by African states: Somalia, the Democratic Republic of the Congo, Sudan, South Sudan and Chad. Moreover, no fewer than 32 African states are represented in the top fifty of the Failed State Index. Worryingly, these include Africa's biggest and most influential states such as Nigeria at number 16, Kenya at number 17, Ethiopia at 19 and Egypt at $34 .^{10}$

The African state has lurched from crisis to crisis since achieving independence. Post-colonial Africa has experienced 85 coups d'état and this figure passes 100 if one takes into consideration the various bloody failed attempts at regime change by various national militaries. ${ }^{11}$ Between 1945 and 2000 there have been 95 conflicts on the continent with over 45 being civil wars ${ }^{12}$. To compound matters further, Africa has hosted some of the longest-running conflicts in recent times $^{13}$. Consider here the fratricidal conflicts in Chad and Sudan lasting four decades or the almost three-decade-long civil war in Angola ${ }^{14}$, or the fact that the sixteen West African states have experienced 82 forms of political conflict, including 44 military coups. ${ }^{15}$ 


\section{The scope and nature of the problem}

One reason for the crisis-prone nature of the African state is the nature of the historical processes, which led to its formation. The colonial era may have been relatively short in duration (roughly from the 1880 s or 1890 s to the 1960 s), but its effect on the subsequent political environment was considerable. ${ }^{16}$ Imperial competition during the 'scramble for Africa' in the $19^{\text {th }}$ century had a profound effect on the formation of the African state and the development of African concepts of security and governance. The enduring colonial legacy is perhaps best seen in the enduring schism between Francophone and Anglophone Africa. Whether it was for economic, strategic or cultural reasons, arguably the most obvious legacy of colonial rule was the division of Africa between the European powers into modern states through agreements ratified at the 1884-85 Berlin Conference (and after), resulting in an uncomfortable fit for Africa's 3315 ethnic groups within Africa's current 54 'nation-states'. 17

Another colonial inheritance which contributed to the reason for the conflictridden nature of African polities is that a tiny elite, usually formed and educated by colonial administrators to assist in the governing of the colonial states, has often been allowed to monopolise the wealth of the nations - giving precious little back to ordinary citizens. President Mobutu Sese Seko's rule (1965-1997) of the former Zaire is perhaps the quintessential example of this. For his entire 32-year rule, Mobutu and his kleptocratic coterie gave his hapless citizens little more than an illdisciplined and predatory military rule while spending practically nothing on public health and educational services. ${ }^{18}$ Despite soaring oil prices benefiting the Nigerian state, the growing impoverishment of the citizenry stands in sharp contrast to the growing wealth of the political elite and perceptions of endemic corruption. Since the end of military rule in 1999, Nigerian politicians have reportedly embezzled between $\$ 4$ billion and $\$ 8$ billion per annum. ${ }^{19}$ At a time when Nigeria's oil revenues were in excess of $\$ 74$ billion per annum, ${ }^{20}$ more than half of Nigerians lived on less than $\$ 1$ a day and four out of ten Nigerians were unemployed. ${ }^{21}$ Under these circumstances, it is easy to see why the Nigerian state would enjoy scarcely any legitimacy among its citizens.

On the one hand, the birth of African international society following independence from the colonial powers in the late 1950s witnessed a reaction against Western imperialism. Consider here policies of non-alignment, for instance. On the one hand, African states of the Non-Aligned Movement rejected the bipolarity of the Cold War but on the other hand, they embraced the form of polity the Westphalian state - and the political borders that the imperial powers imposed 
upon the continent. ${ }^{22}$ There were certainly major obstacles to overcome if Africa was to achieve economic and political development after independence, and many states found themselves in a vulnerable position. ${ }^{23}$ States had to manage divided communities created by arbitrary colonial borders while the newly independent economies had to be diversified and expanded to reduce the levels of mono-crop insecurities and to provide the capital for previously absent basic public services (such as health and education), and institutional mechanisms and ideologies of solidarity had to be found to reduce ethnic tensions. African international society "is intended to provide international political goods that guarantee the survival, security, identity and integrity of African states, which the majority of African states cannot provide individually". 24

Following on the preceding discussion it is important to distinguish between the classic Westphalian state and the African state. Indeed, James Ferguson ${ }^{25}$ powerfully argues that 'the state' may not actually refer to an actor in the African context at all. Rather, he notes, it is a name for a process tying together a multiplicity of formal and informal power relations. Unlike a classic Westphalian state, its African counterpart does not possess a monopoly of coercive force over its territory. The maintenance of political power is dependent upon 'feeding' patronage networks and this compels incumbents to look at ever more sources of wealth. Would-be politicians in these countries also need to acquire wealth in order to unseat incumbents. As a result, both political leaders and their rivals have increasingly turned to crime and organised crime syndicates to bolster their respective war chests. In their seminal study, The criminalization of the African state, Bayart, Ellis and Hibou observe, “... politics in Africa is becoming markedly interconnected with crime". ${ }^{26}$ Christopher Clapham argues that the activities normally associated with states (such as trading and waging war) are often exercised by non-state actors on the territory of the formal African state. ${ }^{27}$ To compound matters still further, those monopolising political power (and resources) in the state often belong to a particular ethnic, racial or religious identity. Those opposing and seeking to replace them, meanwhile, also mobilise along identity lines. Thus, the struggle for political power and material aggrandisement between elites often take the form of identity politics. ${ }^{28}$

Although the on-going violent intrastate conflicts in Africa tend to occur on a much smaller scale than in previous decades (the number of wars has halved since the 1990s), featuring factionalised and divided armed insurgents and occurring on the periphery of states, civil or internal wars remain the dominant form of conflict in Africa. ${ }^{29}$ Apart from the obvious direct effects, armed conflict in Africa often contributes to ancillary outcomes, which create and fuel other problems, such as the 
proliferation of small arms and weapons, food insecurity, environmental degradation, organised crime and public health concerns, among others. ${ }^{30}$ The steady rise of a wide range of non-traditional and transnational threats on the continent, which mirror a global trend in the evolving type and nature of threats facing the international community at large, has been a characteristic feature of the $21^{\text {st }}$-century African security environment ${ }^{31}$. The sheer volume and diversity of these emerging threats on the continent are alarming, as they place unprecedented burdens on states and organisations already poorly resourced and lacking the capacity to respond quickly and effectively to existing security problems. ${ }^{32}$

The next section will provide a brief discussion of the contemporary security threats, both traditional and non-traditional. These are:

- the occurrence of failed states;

- ethnic, racial, religious and communal violence (when taken together, referred to as 'identity conflicts');

- conflicts arising from resource scarcities and environmental degradation;

- $\quad$ the phenomenon of terrorism and extremism;

- $\quad$ trafficking in small arms and light weapons, drugs and people; and

- the persistence of pandemic diseases ${ }^{33}$.

\section{Current manifestations}

The concept of state failure came to prominence in the early 1990s, with the case of Somalia playing a crucial role in shaping the thinking of analysts and scholars about states and state failure. ${ }^{34}$. Failed states have been described variously as those that "can no longer perform the functions required for them to pass as states"; 35 those that "cannot or will not safeguard minimal civil conditions for their populations: domestic peace, law and order, and good governance"; 36 and those in which "public authorities are either unable or unwilling to carry out their end of what Hobbes called the social contract". ${ }^{37}$ The orthodox interpretation of the failed state thesis is closely linked to a view of the modern inter-state system that assumes that all states are essentially alike and therefore function in similar ways. ${ }^{38}$ A state is regarded as successful if it possesses positive sovereignty enabling it to provide a range of the most crucial political goods to its citizenry, which in turn increases the legitimacy of the ruling elite, thereby decreasing the probability of state failure.

Africa's strategic significance as posing a security threat to Western security interests was raised after 9/11, with then Assistant Secretary of State for Africa in the Clinton administration, Susan Rice, describing Africa as the world's "soft underbelly for global terrorism". ${ }^{39}$ Likewise, the September 2002 National Security 
Strategy of the United States of America also changed the calculus of Africa's strategic significance by identifying that "weak states ... can pose as great a danger to our national interests as strong states". ${ }^{40}$ It continues and emphasises that "Poverty does not make poor people into terrorists and murderers. Yet poverty, weak institutions, and corruption can make weak states vulnerable to terrorist networks and drug cartels within their borders." Somalia is often cited as the paradigm of a weak state, if not the very epitome of state collapse, where decades of civil war resulted in state collapse and weak institutions, providing the ideal environment for terrorism (for example), and especially the rise of radical Islam, to thrive in Somalia. ${ }^{41}$

Identity conflict is violence between one or more groups over an actual or perceived threat to the continued maintenance and/or survival of group identity that may be grounded in a shared ethnicity, race, religion or common belief system, language, shared culture and history, geography or occupation - and the group's aspirations within society, which tend to foster an 'us' versus 'them' mentality. Identity conflicts are "usually intransigent and resistant to resolution" as such conflicts are "deeply rooted in the underlying individual human needs and values that together constitute people's social identities, particularly in the context of group affiliations, loyalties, and solidarity."42

Identity conflict most commonly manifests itself in Africa as ethnic, religious or communal violence. As Crawford Young points out, this type of violence "inevitably incorporates discourses of difference" and this "escalates mutual fears, anxieties, and insecurities; communally targeted violence inscribes memories of ineffable loss of kin and fellow ethnics, and inspires dreams of vengeance". ${ }^{43}$ The problem of identity conflict, where multiple identity references become mutually reinforcing, is that societal cleavages take even greater alarming significance in Africa. In this context, the dichotomy between 'us' and the proverbial 'other' becomes more polarising and the concept of common citizenship is ejected from the discourse. The north-south divide in Sudan is arguably the most extreme example of current manifestations of identity conflicts in Africa, where perceived racial (Caucasian/Negroid), religious (Muslim/Christian and animist), cultural (Arab/African), historical (slavers/slaves) and geographical (arid and semiarid/tropical) identities repeatedly divide along the same lines to create an extremely powerful, and seemingly intractable, identity conflict. Although the most common form of conflict pits two or more identity groups against each other, the state itself can also be seen as posing a threat to a group if it is seen as a surrogate form of a competing identity group. If one agrees with Stuart Kaufman's assessment that "identity conflicts are, and will remain for decades to come, the most important 
source of international violence and war in the world", ${ }^{44}$ then the continent and its people are likely to be at the epicentre of this maelstrom.

A common assumption amongst neo-Malthusian security scholars, and even more so amongst policy makers and the media, is that environmental degradation (either in the form of resource scarcity or environmental damage) is a persistent, and growing, cause of violent conflict within and between states. ${ }^{45}$ In fact, Robert Kaplan was so convinced that future conflicts are expected to take on one of two forms - conflict over already scarce resources or military intervention to secure access to resources which might become scarce at some point in the near future that he argued that the environment was:

the national security issue of the early twenty-first century. The political and strategic impact of surging populations, spreading disease, deforestation and soil erosion, water depletion, air pollution, and, possibly, rising sea levels in critical, overcrowded regions like the Nile Delta and Bangladesh - developments that will prompt mass migrations and, in turn, incite group conflicts - will be the core foreign policy challenge from which most others will ultimately emanate. $^{46}$

Evidence suggests that resource competition at community level is relatively prone to violence. ${ }^{47}$ In 2010 and 2011, conflicts over resources accounted for approximately 35 per cent of all conflicts in sub-Saharan Africa and 50 per cent of conflicts in the Americas. On the other hand, only 10 per cent of all conflicts in Europe, the Middle East and Maghreb, and Asia and Oceania featured resources as a cause of conflict.

While terrorism has been a persistent feature of domestic conflicts in Africa for some time, the new danger lies in the growing internationalisation of the threat across the continent or what some, like Jakkie Cilliers, see as "a melding of domestic and international terrorism" to reshape the face of African terrorism. ${ }^{48}$ Beginning in the early 1990s in Algeria and arriving full force in 1998 with the bombing of the American embassies in Kenya and Tanzania, Africa moved into the limelight as a venue for the emerging struggle between the West and international jihadists. Even more alarming is a rising fear that the continent's facilitating environment - weak states, economic and political marginalisation, deep societal divisions, and potentially sympathetic populations - is likely to provide a fertile breeding ground for the growth and export of not just African, but also international, terrorism in the years ahead. The rapid internationalisation of Somalia's Islamist militants - Al-Shabaab - operating through the Somali diaspora is a case in point. 
The quickening pace of globalisation appears to be facilitating this development, as Africa increasingly finds itself becoming part of a new, larger international security order beyond its borders.

A large number of weak states or quasi-states, porous borders, widespread poverty, political frustration, religious radicalism and repression on the African continent combine to create an environment in which the kind of alienation and radicalism that can foster both domestic and international terrorism thrives. ${ }^{49}$ The Nigerian government has embarked on a massive counter-terrorism campaign since July 2009 to bring to heel the violence wrought by the Boko Haram terrorist group throughout northern Nigeria and the capital, Abuja. The strategic significance of AlShabaab from Somalia was raised in the US in 2008, when the then Secretary of State, Condoleezza Rice, designated Al-Shabaab as a foreign terrorist organisation and as a specially designated global terrorist. ${ }^{50}$

With Africa's increasing integration into the global economy and its growing interdependent security relationships with the rest of the world likely to increase over the coming decades, the continent is becoming ever more vulnerable to the dark forces of globalisation that drive international trafficking. The challenge that the illicit trade in drugs, human beings, and small arms brings to the continent is one far beyond the immediate effect of rising transnational criminal activity, but one that has broad implications for the future of African governance and long-term stability. Whether it is the market pull for drugs and people in the industrialised northern hemisphere or the push of small arms into developing countries in conflict, the heavy cost of trafficking falls disproportionally on some of the weakest and most fragile societies on the African continent, adding to a burden that governments and populations can ill afford.

The rise of West Africa as a major transit route for drugs - mostly South American cocaine - into Europe and even the United States is a very recent example, where West African states provided the ideal situation with a conducive political, social and physical environment where "smuggling is widely tolerated, law enforcement fitful or inefficient, and politicians are easily bribed or are even in the drug trade themselves". ${ }^{51}$ Africa has also unfortunately increasingly become part of the global problem of trafficking by serving as a source and a transit point for the trade in women, children and migrants into the labour markets of Europe, the Middle East and North America. Human trafficking and smuggling within and from Africa currently takes place at domestic, sub-regional and transcontinental level and involves sexual exploitation, forced labour and migrant smuggling. The widespread illicit trade in small arms and light weapons completes the deadly African trafficking 
triad and in many aspects, this trade is much more pervasive, ingrained and immediately threatening than the two previous ones. As former UN Secretary General Kofi Annan keenly noted back in 1999, "Indeed, there is no single tool of conflict so widespread, so easily available and so difficult to restrict, as small arms." $^{, 52}$

The final contemporary security threat examined relates to an array of pressing African public health issues that have increasingly come to be seen as a key human security priority for the $21^{\text {st }}$ century. Africa is home to a variety of highly infectious, deadly diseases and, despite the best efforts of African governments, the international community and non-governmental organisations, it is estimated that 2,2 to 2,5 million Africans - many of them vulnerable women and young children die each year as a result of AIDS, malaria, tuberculosis and other infectious diseases. Researchers are increasingly positing that the enormous losses incurred by HIV/AIDS will cause governance crises and pose a major threat to peace and security. ${ }^{53}$ The pandemic is experienced differently on the continent: the southern African epidemic is the worst in terms of high HIV rates, and has spread rapidly. ${ }^{54}$ The HIV/AIDS pandemic unfolded earlier but much slower in East Africa, while the picture in Central and West Africa is highly varied. Whilst the rates of infections have slowed in recent years, the negative bearing of the virus, especially as it affects Africa's middle classes, will remain with the continent for decades to come.

Implications for security

The African state, as evidenced by the previous discussion, is ill-equipped to deal with the security threats that traditional and non-traditional sources shower on the continent. Jakkie Cilliers poignantly summarises the patrimonial nature of the African state, the monopoly of state resources by an elite and the deprivation of the largesse to the bulk of the population:

.... African politics easily degenerates into a life-and-death struggle over private access to limited public resources; the zero-sum nature of the struggle compels would-be political leaders to obtain material benefits in order to wield influence over followers and competitors. Accordingly what all African states share is a generalised system of patrimony and an acute degree of apparent disorder, as evidenced by a high level of governmental and administrative inefficiency, a lack of institutionalisation, a general disregard for the rules of formal political and economic sectors, and a universal resort to personalised and vertical solutions to societal problems. ${ }^{55}$ 
The resultant patronage networks penetrate every facet of the state including, in some instances, its security apparatus. Given the zero-sum nature of politics in the African state as discussed above, violence is often used by an incumbent regime to stay in power, and violence is used by those wishing to effect regime change. The doyen of neo-Realism, Kenneth Waltz, recognised the unique nature of the African context by excluding Africa from his analysis of 'the state' and further remarking that one needs to attain a certain level of self-consciousness as being a political entity before one can legitimately be viewed as a state. ${ }^{56}$ In similar fashion, George Sorenson has also commented on the unique nature of the African context. ${ }^{57}$ The classical security dilemma is turned on its head in that instead of domestic order and international threat there is domestic threat and international order. $^{58}$

A variety of perspectives have been offered by security analysts and academics since the end of the Cold War in an attempt to explain Africa's security dynamics. James Goldgeier and Michael McFaul, for instance, characterise Africa as part of a global periphery wherein security dynamics could be explained in realist terms as part of a Hobbesian struggle for power. ${ }^{59}$ According to this account, whereas liberal international politics is the norm in the global core, calculations of material interest and power balancing dominate as "predictability based on a set of shared norms does not exist" in the periphery. ${ }^{60}$ Barry Buzan and Ole Waever offer a more sophisticated but similar approach, arguing that Africa is caught up in the regionalisation of international security, wherein patterns of enmity and amity, and relative material capabilities within particular 'regional security complexes' are crucial to understanding the continent's security dynamics. ${ }^{61}$

When analysing Africa's security dynamics, however, realist-inspired accounts prove to be problematic for both empirical and conceptual reasons. ${ }^{62}$ In empirical terms, the emphasis of realism on states as unitary, rational and preeminent actors is often inappropriate when one considers the African situation as it firstly obscures the importance of non-state actors and the problematic nature of statehood on a continent where "the dividing line between 'states' and 'non-states' has become so blurred as to be virtually imperceptible". ${ }^{63}$ Second, realist-inspired approaches tend to be poorly equipped to analyse the state-society interactions of a neo-patrimonial nature and their effect on the development of ostensibly "national security' policies. ${ }^{64}$ These accounts also do not reveal much about the attempts of ordinary Africans to provide for their own security, if necessary, by bypassing their states and developing alternative political communities. Realist-inspired approaches are also deficient inasmuch as their focus on material considerations leads to a neglect of the cultural dimensions of Africa's security dynamics. While Buzan and 
Waever acknowledge the importance of non-state actors on the continent in their analysis, their focus on power relations and patterns of amity and enmity downplays the importance of the cultural belief shared by all African states, regardless of their position in the regional distribution of power or their definition of regional friends and enemies. $^{65}$

Throughout the $20^{\text {th }}$ century, states have looked to their immediate neighbours as potential sources of threat or protection. ${ }^{66}$ By focusing on these neighbours, states have sought to develop rules and norms for how states in a particular regional grouping should act. It is argued that, since the regional level is where most of the successful post-1945 security arrangements have been achieved and where the mechanisms and precedents for solutions may already exist, it is the best point of departure to analyse and examine issues pertaining to security threats and their solutions. Barry Buzan argues that the relational nature of security makes it impossible to understand the national security patterns of a state without a firm understanding of the pattern of regional security independence in which it exists. ${ }^{67}$

\section{Regional security structures}

Regionalism implies co-operation among states in geographically proximate and delimited areas for the pursuit of mutual gain in one or more issue areas. ${ }^{68}$ In most of the successful examples of regionalism, states that are already solid partners in political relations (based on shared and complementary values) devolve collective decisions to structures that supplement, rather than supplant, national institutions. Of course, proponents of realism, institutionalism and constructivism differ in their assessment of how states should interact in a post-Cold War era. ${ }^{69}$ Realists argue that, as states are power and security maximisers, they may not cooperate with each other even when they share common interests because the 'self-help' nature of the international system makes cooperation difficult. ${ }^{70}$ Institutionalists agree with realists that state behaviour is based on rational decision-making, but differ in that they view economic and political incentives as just as important as the pursuit for military security. ${ }^{71}$ Constructivists argue that the structures of the international system are not just concerned with the distribution of material resources, but they include social interactions, which help to shape the actors' identities and interests, and not just their behaviour. ${ }^{72}$

Cooperative security is the most effective regional security structure in the post-Cold War era. ${ }^{73}$ As with the two other alternative security structures - common security and comprehensive security - cooperative security attempts to broaden the definition of security beyond the traditional military concerns to include 
environmental, economic and social concerns. Through this process, cooperative security endeavours to change state behaviour from one of competition with other states to cooperation with those states. Non-state actors are given a voice in international forums, and a gradual approach is adopted to promote the development of cooperation while accepting the need for some states to maintain more traditional structures of collective defence as insurance against rivals who may not be as committed to the cooperative process as they claim to be. ${ }^{74}$ Simply put,

what cooperative security really provides is a means to challenge long-held or emergent fears, to overcome the hesitancy that accompanies political risk taking, to lower the walls that have been erected between societies, governments and countries in the wake of the colonial, pre-independence and Cold War periods, and to transcend the barriers of sectarian and national interests. ${ }^{75}$

Cooperative security encourages a constructivist approach to regional security. "The term [cooperative security] tends to connote consultation rather than confrontation, reassurance rather than deterrence, transparency rather than secrecy, prevention rather than correction, and interdependence rather than unilateralism." 76

Based on the preceding discussion on the formation of the African state, it is clear that the rest of this article's approach will be based on the constructivist, cooperative security idea of how African states should interact regionally and subregionally. The existence of an African international society assumes a degree of regional awareness and collective identity to the extent that Africa became what Emanuel Adler called a "cognitive region". ${ }^{77}$ That is to say that, following independence from colonial powers, African state leaders and diplomatic elites perceived themselves to be members of an 'African' international society based on a degree of shared historical experiences and cultural ties. Jackson and Rosberg therefore suggest, "Africa' is a political idea as well as a geographical fact." "78 And at the heart of this notion was the ideology of African nationalism, and even perhaps Pan-Africanism.

\section{The origins of the African Union's security culture}

Security cultures are "patterns of thought and argumentation that establish pervasive and durable security preferences by formulating concepts of the role, legitimacy and efficacy of particular approaches to protecting values". ${ }^{79}$ Security cultures help to establish the core assumptions, beliefs and values of decisionmakers about how security challenges can and should be dealt with through a 
process of socialisation. The African Union's (AU) security culture can be found in the documents and statements of the AU and its officials, in its predecessor (the Organisation for African Unity [OAU]) as well as in foreign policy pronouncements of its member states, particularly expressions of collective identity, solidarity and what counts as appropriate and legitimate conduct. ${ }^{80}$ The AU's security culture comprises a variety of interlocking beliefs that manifest themselves as behavioural norms, i.e. standards of what is considered to be or ought to be right or wrong, and which forbid certain activities and legitimate others - norms are "collective expectations about proper behaviour for a given identity". 81

The discourses about African identity articulated during the $19^{\text {th }}$ and $20^{\text {th }}$ centuries were based on the concept of Pan-Africanism. ${ }^{82}$ The core of the concept referred to the idea "that all Africans have a spiritual affinity with each other and that, having suffered together in the past, they must march together into a new and brighter future" - the suffering, of course, referring to the colonial and slave trade periods. ${ }^{83}$ The first formal discussions of Pan-Africanism took place during the $19^{\text {th }}$ century outside of Africa (in the Caribbean, North America and Europe), and very few Africans participated in the Pan-African congresses until the fifth one, held in Manchester in 1945, where approximately one third of the delegates were African descendants. The first conference of the (then eight) independent African states was held in 1958 in Accra, Ghana. The Pan-African movement also enjoyed some support from Asia's newly independent states, particularly through the so-called 'spirit of Bandung', which became an important rallying call in both continents after the 1955 conference in Bandung, Indonesia. Apart from encouraging the campaign against apartheid in South Africa, Pan-Africanism made little practical headway and failed to instigate the formation of a pluralist society of sovereign states in Africa. ${ }^{84}$

\section{The establishment of the Organisation for African Unity}

The establishment of the OAU was a crucial moment in the process of norm socialisation in Africa. ${ }^{85}$ The OAU was established in 1963 out of what Colin Legum describes as "historic necessity and a welter of conflicting political ideas and interests" ${ }^{86}$ Haile Selassie noted at the time that the idea behind the establishment of the OAU was to "create a single institution to which we will all belong, based on principles to which we all subscribe" ${ }^{87}$ This, however, was easier said than done. The eventual formation of the OAU reflected a rather fragile compromise between three distinct (and often competing) geopolitical currents that ran through the continent at the time, namely, Francophone, Anglophone and Arab. ${ }^{88}$ The resultant ideological rifts within the continent produced by the early 1960s three major groups 
of African states known as the Brazzaville, Casablanca and Monrovia blocs. The existence of the Brazzaville bloc was rather short-lived (it later joined the Monrovia bloc). In the run-up to the establishment of the OAU, the Monrovia and Casablanca groups disagreed over two main issues. The first issue was about how to liberate Africa from European rule. The main point of contention here was whether or not to endorse the National Liberation Front's struggle against the French in Algeria. The second issue pertained to the territorial partition of the continent. ${ }^{89}$ By the time of the OAU negotiations, two competing visions of African unity had arisen:

- the first was dubbed the 'United States of Africa' where Kwame Nkrumah and Julius Nyerere argued for a single continental government; and

- the second vision was that of African unity called the 'United Nations of Africa', which won the day and was exemplified by the creation of an organisation of newly independent sovereign African states, the OAU.

Four of the OAU's subsequent 'articles of faith', as set out in Article 3 of its Charter in particular, provided the foundation for the organisation's security culture. ${ }^{90}$ First, imperialism was identified as the principle obstacle to achieving African unity, which meant that African disputes had to be quarantined from external, non-African influences. The second principle was that of sovereign equality, and as Legum observes, "consensus politics is, in fact, a crucial aspect of the "African way of doing things"". 91 The third principle relates to the institutionalisation of the norm of non-intervention in line with the United Nations Charter and the principle of sovereign equality. As Nyerere stated, this norm meant "we must avoid judging each other's internal policies, recognising that each country has special problems". 92 The final principle that contributed to the OAU's security culture was that of uti possidetis ${ }^{\mathrm{a}}$.

At a Council of Ministers meeting in 1979, the OAU decided to divide Africa into five sub-regions corresponding to the number of regional economic communities (RECs) in existence at the time while promoting the establishment of others at the same time: Northern, Southern, Western, Eastern and Central Africa. ${ }^{93}$ The 1991 Abuja Treaty, which sought to rationalise the Pan-African and regional agendas, established that the RECs would form part of the constitutive elements of a Pan-African integration agenda. The AU has retained this organisational structure. More of this will be discussed later.

${ }^{\text {a }}$ Uti possidetis is the legal doctrine that colonial administrative boundaries would become international boundaries when the political unit in question achieved independence. Williams, PD. "From non-intervention to non-indifference: The origins and development of the African Union's security culture". African Affairs 106/423. 2007. 261. 
Notwithstanding the adoption in 1981 of the African Charter on Human and Peoples' Rights, which listed all the civil rights as well as numerous secondgeneration rights, the OAU did not fare very well in the promotion of human rights. ${ }^{94}$ Even though it was decided in 1998 to strengthen the human rights regime with the establishment of the African Court on Human and Peoples' Rights, the Court only entered into force in January 2004, after the OAU had been replaced by the AU. The OAU also did not fare very well in the field of directly security-related activities. ${ }^{95}$ Although the organisation managed to institutionalise a number of norms and standards, the OAU was never able to enforce them effectively on the member states. Arguably the most poignant example in this regard is the outlawing of the use of 'dogs of war' or mercenaries with the 1985 Convention for the Elimination of Mercenarism in Africa, which has had little preventive powers in the use of mercenaries and private military companies by states such as Sierra Leone during its protracted civil war.

Besides the setting of standards and norms, the OAU also took institutional steps to upgrade its conflict prevention and management capacity. ${ }^{96}$ The AU, for example, incorporated the 1993 Declaration on the Establishment of the OAU of a Mechanism for Conflict Prevention, Management and Resolution (MCPMR) into its enforcement mechanism under the AU Peace and Security Council (AUPSC). ${ }^{97}$ The OAU also ventured into the field of peace support operations in Chad (1981-1982), Rwanda (1990-1993), Burundi (1993-1996) and the Comoros (1997-1999) on a couple of occasions, all of which were singularly ineffective to most accounts.

The central tenets of the OAU's security culture did not remain static but developed in response to a variety of internal and external factors, eventually producing two new norms related to unconstitutional governments and humanitarian intervention. $^{98}$

\section{The African Union}

The ambitious design of the AU as the successor of the OAU, as set out in its 2000 Constitutive Act (CAAU), was already taking shape at a remarkable pace in 2004. ${ }^{99}$ Less than two years after the AU's inauguration in Durban, South Africa, member states were already busy moving from the paper and ratification process to the launch of two key organs of the organisation: the Peace and Security Council (PSC) and the Pan-African Parliament (PAP). The new institutions were intended to ensure a greater degree of enforcement and oversight of the AU's decisions. The perceived weakness of the OAU was that it lacked both the will and the means to enforce its decisions given that commitments made by heads of states and 
governments to peace and security, respect for democracy, human rights and the rule of law, were often broken with impunity.

The CAAU underlined the need to "promote peace, security and stability as a prerequisite for the implementation of our development and integration agenda" (Art. 3f), just as it expressed the determination to promote and protect human and peoples' rights, consolidate democratic institutions and culture, and to ensure good governance and the rule of law (Art. $3 \mathrm{~h}$ and $3 \mathrm{~g}$ ). ${ }^{100}$ One could argue that there are seven norms, which the AU adopted and institutionalised that constitute the AU's central tenets of its security culture (as contained in the CAAU):

- $\quad$ sovereign equality of members (Art. 4a);

- $\quad$ non-intervention by member states (Art. 4g);

- anti-imperialism/African solutions first;

- $\quad$ uti possidetis (Art. 4b);

- $\quad$ non-use of force/peaceful settlement of disputes (Art. 4e, 4f, 4i);

- $\quad$ condemnation of unconstitutional changes of governments (Art. 4p); and

- the Union's right to intervene in a member state in grave circumstances (Art. 4h). ${ }^{101}$

What is of particular interest is the decision to establish the continent's first continent-wide, regional, collective security system, the AUPSC. It was agreed at the Addis Ababa Summit in July 2002 to establish the AUPSC, intended as "an operations structure for the effective implementations of the decisions taken in the areas of conflict prevention, peace-making, peace support operations and intervention, as well as peace-building and post-conflict reconstruction". ${ }^{102}$ The AUPSC joined the ranks of the Economic Community of West African States Mechanism on Conflict Prevention, Management and Resolution, Peace-Keeping and Security (ECOWAS Mechanism) and the South African Development Community Organ of Politics, Defence and Security Cooperation (SADC Organ) as one of the three African mechanisms established to manage the conflict on the continent through, inter alia, military intervention and diplomacy. ${ }^{103}$

The African Union's Peace and Security Council

The Protocol on the AUPSC entered into force on 26 December 2003 following ratification by 27 of the AU's 54 member states. ${ }^{104}$ The Protocol on the AUPSC was adopted pursuant to Article 5(2) of the CAAU "as a standing decisionmaking organ for the prevention, management and resolution of conflicts" and to serve as "a collective security and early-warning arrangement to facilitate timely and efficient response to conflict and crisis situations in Africa". ${ }^{105}$ Under Article 22, the 
AUPSC replaced the Cairo Declaration and superseded the resolutions and decisions of the OAU's MCPMR. ${ }^{106}$ The objectives of the AUPSC are therefore not new to the African political landscape, and they complement the principles enshrined in Article 3 of the CAAU ${ }^{107}$ while echoing the collective security framework suggested by the 1991 Draft Kampala Document for the Conference on Security, Stability, Development and Cooperation in Africa. ${ }^{108}$

Objectives

The key objectives of the AUPSC are to -

- $\quad$ promote peace, security and stability ${ }^{109}$;

- $\quad$ guarantee the protection and preservation of life and all property, the wellbeing of the African people and their environment, as well as the creation of conditions conducive to sustainable development; ${ }^{110}$

- $\quad$ anticipate and prevent conflicts; ${ }^{111}$

- $\quad$ promote and implement peace-building and post-conflict reconstruction activities; ${ }^{112}$

- co-ordinate and harmonise continental efforts in the prevention and combating of international terrorism; ${ }^{113}$

- develop a common defence policy; ${ }^{114}$ and

- $\quad$ promote and encourage democratic practices, good governance and the rule of law; protect human rights and fundamental freedoms; respect for the sanctity of human life and international humanitarian law. ${ }^{115}$

\section{Composition}

The composition of the AUPSC is not entirely unique and in some ways it even reflects the structure of the United Nations Security Council (UNSC), particularly on issues concerning membership, core functions and the voting process. ${ }^{116}$ This may be, in part, because the AU relied on UNSC staff and advisors during the drafting of the Protocol. One glaring difference, however, is that the AUPSC's composition is much more democratic than that of the UNSC as it does not have any provisions for permanent membership. Similar to the UNSC, the AUPSC is composed of fifteen members who serve two- and three-year terms. ${ }^{117}$ AUPSC members are "elected on the basis of equal rights" and according to the "principle of equitable representation and rotation". ${ }^{118}$ Prospective members are selected according to numerous criteria, including their ability and willingness to uphold, promote, financially support and advocate the principles of the AU and to 
participate actively in sub-regional and regional peace-making and peace support operations. $^{119}$

\section{Powers}

The AUPSC is empowered to carry out several important functions that complement and contradict the other security mechanisms already in existence at the time of establishment, including the ECOWAS Mechanism, the SADC Protocol and the Inter-Governmental Authority on Development (IGAD) conflict mechanism. The ECOWAS Mechanism and SADC Protocol will be discussed in more detail in subsequent sections. It is interesting to note that the IGAD Mechanism made no provision for peacekeeping and/or peace enforcement. ${ }^{120}$ Some of the extraordinary powers that the AUPSC have are included in Article 7 of the Protocol, and the Council may:

- $\quad$ authorise the mounting and deployment of peace support missions;

- recommend to the Assembly to intervene in a member state in case of grave circumstances, namely war crimes, crimes against humanity and genocide;

- institute sanctions whenever an unconstitutional change of government takes place;

- $\quad$ implement the common defence policy of the AU;

- follow up on progress made by member states towards the promotion of democratic practices, good governance, the rule of law, protection of human rights and fundamental freedoms, respect for the sanctity of human life and international humanitarian law; and

- $\quad$ support and facilitate humanitarian action in situations of armed conflicts or major environmental disasters. ${ }^{121}$

Organs

The AUPSC Protocol also made provision for the establishment of three noteworthy operational organs: the Panel of the Wise, the Continental Early Warning System (CEWS) and the African Standby Force (ASF). ${ }^{122}$ The Panel advises and supports the "efforts of the Peace and Security Council and those of the Chairperson of the Commission, particularly in the area of conflict prevention" and on "all issues pertaining to the promotion and maintenance of peace, security and stability in Africa". ${ }^{123}$ The Panel comprises five eminent African personalities who have made an "outstanding contribution to the cause of peace, security and development on the continent". ${ }^{124}$ The Panel has also produced a number of 
thematic reports on issues relevant to peace and security on the continent, such as matters relating to non-impunity, women and children in conflicts, and electoral disputes. $^{125}$

A growing realisation of the importance of proactive measures to prevent conflicts rather than reactive measures to deal with conflicts resulted in the creation of the CEWS. The CEWS is an appendage of the OAU's MCPMR, which was also integrated into the AUPSC, and is mandated to supply the Commission (AU Secretariat) with timely information and analysis "to advise the Peace and Security Council on potential conflicts and threats to peace" and to recommend courses of action with the purpose of taking early action. ${ }^{126}$ The Protocol states that the CEWS will consist of an "observation and monitoring center" that will be referred to as the "Situation Room", which will be responsible for the collection of data and its analysis relating to conflict on the continent. ${ }^{127}$ It was envisaged that the CEWS would be linked to sub-regional conflict mechanisms in the five sub-regions of Africa, including the ECOWAS Mechanism, the SADC Organ and the IGAD Mechanism. ${ }^{128}$ A further five sub-regional and REC mechanisms also form part of the CEWS system, including the Arab Maghreb Union (AMU), the East African Community (EAC), the Common Market for Eastern and Southern Africa (COMESA), the Economic Community of Central African States (ECCAS) and the Community of Sahel and Saharan States (CEN-SAD). ${ }^{129}$

The ASF is arguably the most important organ in the AUPSC framework. ${ }^{130}$ More than ever before, it was realised that there was an urgent need for robust responses to the challenges of peace and security on the continent. ${ }^{131}$ In May 2003, the African Chiefs of Defence and Security began deliberations on how the AU could conduct interventions into states with identifiable 'grave circumstances' while conforming to the principles of non-interference and the responsibility to protect enshrined in the CAAU. Towards the end of 2004, what emerged was the creation of an ASF operating under the auspices of the AUPSC. ${ }^{132}$ The ASF is a rapid deployment force "composed of standby multidisciplinary contingents, with civilian and military components". ${ }^{133}$ It is sanctioned to conduct several types of operations, including:

- observation and monitoring missions; ${ }^{134}$

- $\quad$ other types of peace support missions; ${ }^{135}$

- intervention in a member state in respect of grave circumstances or at the request of a member state in order to restore peace and security, in accordance with Article 4(h) and (j) of the CAAU; ${ }^{136}$

- $\quad$ preventive deployment in order to prevent (i) a dispute or a conflict from escalating, (ii) an ongoing violent conflict from spreading to neighbouring 
areas or states, and (iii) the resurgence of violence after parties to a conflict have reached an agreement; ${ }^{137}$

- peace-building, including post-conflict disarmament and demobilisation; ${ }^{138}$

- humanitarian assistance to alleviate the suffering of civilian populations in conflict areas and support efforts to address major natural disasters; ${ }^{139}$ and

- $\quad$ any other functions as may be mandated by the Peace and Security Council or the Assembly. ${ }^{140}$

The ASF was to be organised into five regional brigades (each comprising 5000 personnel bringing the total to 25000 personnel) to correspond with the existing five regional groupings of the AU:

- $\quad$ the Southern African Development Community Brigade (SADCBRIG);

- $\quad$ the East African Peace and Security Mechanism known more commonly as the Eastern Africa Standby Brigade (EASBRIG);

- $\quad$ the North African Regional Capability Brigade, better known as the North African Standby Brigade (NASBRIG);

- $\quad$ the Economic Community of West African States Brigade (ECOBRIG); and

- the Economic Community of Central African States Brigade (ECCASBRIG) also known as the Multinational Force of Central Africa. $^{141}$

It is expected that the ASF will be fully operational by $2015 .^{142}$ Should preventive diplomacy through either the chairperson of the Commission or the Panel of the Wise fail in conflict resolution attempts, the AUPSC system should trigger the rapid deployment of a standby force of peacekeepers to prevent or reduce bloodletting. ${ }^{143}$

The African Union Peace and Security Council and sub-regional security mechanisms

The sub-regional conflict mechanisms of sub-regional bodies such as ECOWAS, SADC and IGAD "are part of the overall security architecture of the Union". ${ }^{144}$ In this context, the AU commits itself to "harmonise and coordinate" 145 and partner with sub-regional mechanisms to achieve peace, security and stability on the continent through the exchange of information and analyses, ${ }^{146}$ and the establishment of liaison offices in the regional mechanisms. ${ }^{147}$ Although the AU's proposed collective security framework is much more democratic, transparent and 
inclusive than that of its predecessor, the OAU, there are a couple of worrying stumbling blocks related to inter-African regional conflicts of law which exist among the AU, ECOWAS and SADC that have not enjoyed sufficient attention by the AU. ${ }^{148}$

Since the end of the Cold War, it has become increasingly fashionable to suggest that regional and sub-regional organisations should play a more prominent role in the political, economic and security sectors, a concept that is based on the principle of subsidiarity. ${ }^{149}$ The AUPSC has assigned itself primary responsibility for promoting peace, security and stability in Africa, a designation that in the jurisdictional sense supersedes any such claim made by other African organisations. ${ }^{150}$ The AU pays due tribute to the subsidiarity principle 'upwards' by acknowledging the supreme authority in matters of peace and security of the UNSC. ${ }^{151}$ As for the implications 'downwards', though, the matters are less clear. The AU views sub-regional organization not as instances of first resort, but there are referred to as implementing organs of the AU. ${ }^{152}$

The intervention by ECOWAS in Liberia in 1990 brought the organisation to international attention, in part because it showed the world that regional structures will not stand idly by whilst massive crimes are perpetrated by the different factions involved in conflict. Furthermore, the conceptual and empirical sanctity of the norms of sovereignty and non-intervention in a state's affairs will not serve as a barrier behind which massive crimes can be perpetrated. The ECOWAS intervention in Liberia was regarded as a success. Likewise, the assistance of a large Nigerian-led military ECOWAS force led to the successful restoration of Kabbah as president in Sierra Leone in 1998. ${ }^{153}$ In both cases, ECOWAS established its Cease-fire Monitoring Group, ECOMOG, which helped to restore peace and stability to these two countries. ${ }^{154}$ Both interventions were merely supplemented and supported by UN missions (UNMIL in Liberia and UNOMSIL and later UNAMSIL in Sierra Leone) and it is thus argued that regional organisations - although suffering from some structural malaises, such as a lack of financial and manpower support - are able to react to a conflict situation in their region much quicker, with expert knowledge of the region not necessarily available to regional or international organisations, even if it is only until it can be supported and/or supplemented by an AU or UN mission.

The extent to which regional organisations are better suited than global or even regional institutions (such as the UN and AU respectively) to respond adequately to the security and developmental problems confronted by the world's different regions remains a matter of debate to students and practitioners of 
international relations. ${ }^{155}$ The laws of intervention of the AU and ECOWAS are complementary. ${ }^{156}$ The AU under both the CAAU and the AUPSC Protocol may authorise interventions to forestall war crimes, crimes against humanity and genocide. Similarly, the ECOWAS, under both the Framework Establishing the ECOWAS Mechanism for Conflict Prevention, Management, Resolution, PeaceKeeping and Security, and the ECOWAS Mechanism, may invoke a right of 'humanitarian intervention' in three specific cases. However, the law of the SADC as prescribed in the SADC Organ on Politics, Defence and Security and the SADC Protocol on Politics, Defence and Security Co-Operation contradicts the law of the AU and ECOWAS. ${ }^{157}$ SADC law permits interventions to remedy war crimes, crimes against humanity and genocide, ${ }^{158}$ and to forestall military coups or other threats to legitimise authority, ${ }^{159}$ but forbids any such action without prior authorisation from the UNSC. Furthermore, one of the guiding principles of the SADC Organ is that military intervention of whatever nature shall be decided upon only after all possible political remedies have been exhausted in accordance with the AU Charter and UN Charter. ${ }^{160}$

However, the prominent role that the AU has assigned to sub-regional organisations and RECs will allow the AU to build on their comparative advantage, experience and established frameworks and mechanisms for conflict prevention, management and resolution. ${ }^{161}$ The proximity of sub-regional organisations to the conflict provides them with a better understanding of its dynamics, key players and context-specific management and resolution options. Sub-regional leaders and organisations may also be considered to be more accountable and legitimate in their pursuits than Pan-African and international organisations, and they therefore may have a greater stake in finding a peaceful solution to the conflict.

\section{Outlook}

The article set out by examining the complexities and intricacies of the African state, which were inherited through the historical processes of its formation. In many cases, the African state is plagued by widespread corruption, it does not possess a monopoly of coercive force over its territory, and it has to grapple with processes of endeavouring to tie a multiplicity of formal and informal power relations together. The resultant predatory states are therefore ill-equipped to deal with the security threats that traditional and non-traditional sources discussed in this article shower on the continent.

A variety of perspectives have been offered by security analysts and academics since the end of the Cold War in an attempt to explain Africa's security 
dynamics. It was identified in this article that, due to the unique nature of the African state and the emergence of non-traditional security threats on the continent, a realist-inspired approach to solving the continent's security issues would be futile, as has been the case in the past. Rather, a cooperative security structure approach through the AU and the sub-regional organisations in Africa seems to be the most effective approach to solving some of the continent's security dynamics. The development of the AU's security culture, which it inherited from its predecessor, the OAU, is very important in this regard as it led to the creation of a continent-wide peace and security architecture, as embodied in the AUPSC.

While regional and sub-regional engagements in peace support operations have been encouraging, and promoted by the UN and other donors' support, there are still gaps. ${ }^{162}$ The same commitment to the peace support operations by the subregional and regional actors have not been translated fully to such areas as biosecurity and public health, climate change, energy security, food security, resource security, cyber security and demographic trends. These non-traditional security issues often require long-term commitments, and due to the nature of Africa's many impoverished states and the continent's inability to provide resources and commitment for long-term projects, security issues have principally been the responsibility of international organisations, aid agencies and development partners.

In all these institutional processes, one other dynamic force for change and source of response capacity is the role that civil society can play on the continent. ${ }^{163}$ Due to its proximity to conflict areas, civil society has been able to work at grassroots level in areas where some international organisations are reluctant to venture, and international organisations have increasingly channelled resources through civil society in these circumstances. Civil society groups are very often also engaged in democratisation processes in Africa through mass campaigns and education. African civil society therefore has a role to play in improving the performance of African states and regional and sub-regional organisations. One example of civil society's positive contribution to the reformation of Africa's security dynamics is in the area of small arms and light weapons proliferation in West Africa, where civil society groups have worked together with ECOWAS to assist in the disarmament processes and to assist in capacity building to address this major security concern to the sub-region. ${ }^{164}$

The AU's ambitious security architecture reform mechanisms are still in their embryonic stages, and it will be interesting to see how they develop the capacities to promote peace, security and stability on the continent. No matter how popular the phrase 'African solutions to African problems' may be, the fact of the 
matter is that Africa's states, RECs, sub-regional and regional organisations are currently not able to conduct any sustained or long-term peace support operations on the continent without the requisite economic, logistical and political commitment and technological capacity of external donors, such as the United States, France, the United Kingdom and the European Union. What is therefore a much more likely scenario in attempting to address Africa's security dynamics is the blending of support from development and peace operations partners with the efforts of the subregion and region, with critical emphasis placed on African input and political and strategic direction. ${ }^{165}$ That is not to say, however, that the AU's ambitious security architecture reform mechanisms are completely futile or that its endeavours should not be undertaken. In fact, the $\mathrm{AU}$ and the sub-regional organisations have succeeded in bringing at least relative peace to some areas of the continent.

\section{Endnotes}

${ }^{1}$ Professor Hussein Solomon lectures in the Department of Political Studies and Governance at the University of the Free State, South Africa. He wishes to acknowledge the financial support from the National Research Foundation, which made this publication possible. He however takes sole responsibility for the contents of this article.

${ }^{2}$ Williams, PD. "From non-intervention to non-indifference: The origins and development of the African Union's security culture". African Affairs 106/423. 2007. 253.

${ }^{3}$ Fierke, KM. "Constructivism," in Dunne, T., Kurki, M. and Smith, S (eds.) International Relations Theory: Discipline and Diversity. $2^{\text {nd }}$ edition. Oxford University Press. Oxford. 2010, pp. 177-193.

4 “Africa's hopeful economies". The Economist. 3 December 2011.

${ }^{5}$ Ibid. <http://www.economist.com/node/21541008> Accessed on 8 August 2013.

${ }^{6}$ Ibid.

${ }^{7}$ African Development Bank. African Statistical Yearbook. Tunis, 2013, 30-36.

${ }^{8}$ Freedom House. "Freedom in the world 2013: Democratic breakthroughs in the balance". 2013.

<http://www.freedomhouse.org/report/freedomworld/freedom-world-2013> Accessed on 8 August 2013.

${ }^{9}$ Zakariya, F. "After the coup: Egypt must reach out to the Islamists it is now jailing". Time. 22 July 2013. 23.

${ }^{10}$ The Fund for Peace. "2013 Failed State Index". 2013. <http://ffp.statesindex.org> Accessed on 8 August 2013.

${ }^{11}$ Araoye, A. "Hegemonic agendas, intermesticity and conflicts in the post-colonial state". African Journal on Conflict Resolution 12/1. 2012, p. 10. 
${ }^{12}$ Solomon, H. "Analysing Conflicts," Searching for Peace in Africa: An Overview of Conflict Prevention and Management Activities. Utrecht: European Centre for Conflict Prevention, 2000, p. 34.

${ }^{13}$ Reychler, L. "Conflicts in Africa - the issues of control and prevention," in Report of the Commission on African Regions in Crisis, Conflicts in Africa: An Analyysis of Crises and Crisis Prevention Measures. Brussels. European Institute for Research and Information on Peace and Security. 1997, p. 17.

${ }^{14}$ Rupesinghe, K. and Anderlini, S.N. Civil Wars, Civil Peace: An Introduction to Conflict Resolution. London: Pluto Press. 1998, p. 2.

${ }^{15}$ Araoye, op. cit., p. 10.

${ }^{16}$ Thomson, A. An introduction to African politics ( $2^{\text {nd }}$ ed). Abingdon: Routledge, $2004,11$.

${ }^{17}$ NumberOf.net. "Number of ethnic groups in Africa". $<$ http://www.numberof.net/number-of-ethnic-groups-in-africa $>$ Accessed on 25 June 2014.

${ }^{18}$ Williams, PD. "Security studies: An introduction". In Williams, PD (ed.), Security studies: An introduction ( $2^{\text {nd }}$ ed), London: Routledge, 2013, 2.

${ }^{19}$ Griswold, E. The tenth parallel: Dispatches from the fault line between Christianity and Islam. London: Penguin Books, 2010, 19.

${ }^{20}$ International Crisis Group. "Nigeria's elections: Reversing the degeneration?" Africa Policy Briefing No 79. 24 February 2011.

${ }^{21}$ Griswold op. cit., p. 19.

${ }^{22}$ Williams, "From non-intervention ..." op. cit., p. 260.

${ }^{23}$ Thomson op. cit., p. 21.

${ }^{24}$ Jackson, RH \& Rosberg, CG. "Why Africa's weak states persist: The empirical and the juridical statehood". World Politics 35/1. 1982. 19.

${ }^{25}$ Quoted in Araoye op. cit., p. 15.

${ }^{26}$ Quoted in Cilliers, J. "Terrorism and Africa". Africa Security Review 12/4. 2003. 100.

${ }^{27}$ Quoted in Smith, K. "Has Africa got anything to say? African contributions to the theoretical development of international relations". The Roundtable: The Commonwealth Journal of International Affairs 98/402. 2010. 273-274.

${ }^{28}$ Araoye op. cit., p. 11.

${ }^{29}$ Cilliers, J \& Schünemann, J. "The future of intrastate conflict in Africa: More violence or greater peace?” Institute for Security Studies Paper No 246. May 2013. 2.

${ }^{30}$ Aning, K. "Africa: Confronting complex threats". Coping with Crisis Working Paper Series. The International Peace Academy. February 2007. $<$ http://africacenter.org/wp-content/uploads/2007/07/Africa-ConfrontingComplex-Threats.pdf > Accessed on 10 March 2014.

${ }^{31}$ Ibid.

${ }^{32}$ Ibid. 
${ }^{33}$ United Nations Environmental Programme. "Diseases and development challenges in Africa," Encyclopaedia of Earth. 24 August 2008. Internet: http://www.eoearth.org/view/article151750. Date accessed: 30 April 2015.

${ }^{34}$ Call, CT. "The fallacy of the 'failed state"'. Third World Quarterly. 29/8. 2008. 1492.

${ }^{35}$ Zartman, IW. "Introduction: Posing the problem of state collapse". In Zartman, IW (ed), Collapsed states: The disintegration and restoration of legitimate authority, Boulder, CO: Lynne Rienner, 1995, 5.

${ }^{36}$ Jackson quoted in Hill, J. "Beyond the other? A postcolonial critique of the failed states thesis". African Identities 3/2. 2005. 145.

${ }^{37}$ Gros, J-G. "Towards a taxonomy of failed states in the new world order: Decaying Somalia, Liberia, Rwanda and Haiti”. Third World Quarterly 17/3. 1996. 456.

${ }^{38}$ Bøås, M \& Jennings, KM. "“Failed states' and 'state failure': Threats or opportunities?” Globalizations 4/4. 2007. 477.

${ }^{39}$ Rice, S. "Testimony before the US House Committee on International Relations". November 2001. <http://commdocs.house.gov/committees/intlrel/hfa76191.000/hfa76191 0f. $\underline{\mathrm{htm}}>$ Accessed on 12 February 2014.

40 The White House. "National Security Strategy of the United States of America". September 2002. <http://www.state.gov/documents/organization/63562.pdf> Accessed on 12 February 2014.

${ }^{41}$ Walls, M. "The emergence of a Somali state: Building peace from civil war in Somaliland". African Affairs 108/432. 2011. 371.

${ }^{42}$ Rothman, J. Resolving identity-based conflict in nations, organizations, and communities. San Francisco, CA: Jossey-Bass, 1997, 6.

${ }^{43}$ Young, C. "Deciphering disorder in Africa: Is identity the key?" World Politics 54. July 2002. 556.

${ }^{44}$ Kaufman, S. "Social identity and the roots of future conflict". NIC 2020 discussion paper. October 2003. 1.

${ }^{45}$ Page, E. "What's the point of environmental security?" Paper presented for the SGIR at the $7^{\text {th }}$ Pan-European International Relations Conference, Stockholm, 10 September 2010, 13.

${ }^{46}$ Kaplan, R. "The coming anarchy”. The Atlantic Monthly 273/2. 1994. 58.

${ }^{47}$ Heidelberg Institute for International Conflict Research. "Conflict barometer". 2011, Internet: www.hiik.de/en/konflikbarometer. Date accessed: 5 January 2014. 4.

${ }^{48}$ Cilliers op. cit., p. 101.

${ }^{49}$ Mills, G. “Africa's new strategic significance”. The Washington Quarterly 27/4. 157-169.

${ }^{50}$ Rice, C. "Designation of al-Shabab". Office of the Coordinator for Counterterrorism. 18 March 2008. <http://www.state.gov/j/ct/rls/other/des/143205.htm> Accessed on 12 February 2014. 
${ }^{51}$ Ellis, S. "West Africa's international drug problem". African Affairs 108/431. April 2009. 173.

52 "Addressing the Security Council, Secretary-General Says International Community Must Revere Global Proliferation of Small Arms". United Nations, SG/SM/7145, SC/6733, 24 September 1999.

${ }^{53}$ De Waal, A. "How will HIV/AIDS transform African governance?". African Affairs 102. 2003. 1.

${ }^{54}$ Ibid., p. 3.

${ }^{55}$ Cilliers op. cit., p. 98.

${ }^{56}$ Schouten, P. "Theory Talks No 40: Kenneth Waltz - The physiocrat of international politics". Theory Talks. <http://www.theorytalks.org/2011/06/theory-talk-40.html.4 June 2011> Accessed on 12 February 2014

${ }^{57}$ Araoye op. cit., p. 13.

${ }^{58}$ Ibid.

${ }^{59}$ Goldgeier, JM \& McFaul, M. "A tale of two worlds: Core and periphery in the post-Cold War era”. International Organization 46/2. 1992. 467-491.

${ }^{60}$ Ibid., p. 478.

${ }^{61}$ Buzan, B \& Waever, O. Regions and powers: The structure of international security. Cambridge: Cambridge University Press, 2003.

${ }^{62}$ Williams, "From non-intervention ..." op. cit., p. 254.

${ }^{63}$ Clapham, C. "Degrees of statehood”. Review of International Studies 24/2. 1998. 153.

${ }^{64}$ Williams, "From non-intervention ..." op. cit., p. 255.

${ }^{65}$ Buzan \& Waever op. cit., p. 49.

${ }^{66}$ Snyder, CA. "Regional security structures". In Snyder, CA (ed.), Contemporary security and strategy, Basingstoke: Macmillan, 1999, 102.

${ }^{67}$ Quoted in Snyder op. cit., p. 102.

${ }^{68}$ Malan, M. "The OAU and African subregional organisations: A closer look at the 'peace pyramid"'. Institute for Security Studies Occasional Paper No 36. January 1999. 1.

${ }^{69}$ Snyder op. cit., pp. 103-105.

${ }^{70}$ Mearsheimer, JJ. "Correspondence: Back to the future, Part II: International relations theory and post-Cold War Europe". International Security 15/2. 1990. 198.

${ }^{71}$ Keohane, RO \& Nye, JS Jr. "Power and interdependence revisited". International Organisation 41/4. 1987. 728-729.

${ }^{72}$ Snyder op. cit., p. 104.

73 Ibid., p. 117.

${ }^{74}$ Ibid.

75 Ibid., p. 114.

76 Ibid.

${ }^{77}$ Adler, E. "Imagined (security) communities: Cognitive regions in international relations”. Millennium: Journal of International Studies 26/2. 1997, p. 251. 
78 Jackson \& Rosberg op. cit., p. 17.

${ }^{79}$ Williams, "From non-intervention ..." op. cit., p. 256.

${ }^{80}$ Ibid., p. 257.

${ }^{81}$ Ibid., p. 258.

${ }^{82}$ Emerson, R. "Pan-Africanism”. International Organization 16/2. 1962.

${ }^{83}$ Ibid., p. 280.

${ }^{84}$ Ibid., p. 288.

${ }^{85}$ Williams, "From non-intervention ..." op. cit., p. 263.

${ }^{86}$ Legum, C. "The organisation of African unity - success or failure?" International Affairs 51/2. 1975. 208.

${ }^{87}$ Selassie, HI. "Towards African unity". Journal of Modern African Studies 1/3. 1963. 285.

${ }^{88}$ Legum op. cit., p. 209.

${ }^{89}$ Williams, "From non-intervention ..." op. cit., p. 264.

${ }^{90}$ Selassie op. cit., p. 287.

${ }^{91}$ Legum op. cit., p. 214.

92 Nyerere, JK. “A United States of Africa”. Journal of Modern African Studies 1/1. 1963. 5.

${ }^{93}$ Powell, K. "The African Union and the regional mechanisms for conflict prevention, management and resolution”. In Powell, K (ed), The African Union's emerging peace and security regime: Opportunities and challenges for delivering on the responsibility to protect. ISS Monograph Series No 119. May 2005. 19.

${ }^{94}$ Møller, B. "The African Union as security actor: African solutions to African problems?" Crisis States Working Papers Series No 2, Working Paper No 57. August 2009. 6.

95 Ibid.

${ }^{96}$ Ibid., p. 7.

${ }^{97}$ Levitt, JL. "The Peace and Security Council of the African Union: The known unknowns". Transnational Law and Contemporary Problems 13/109. Summer 2003. 110.

${ }^{98}$ Williams, "From non-intervention ..." op. cit., p. 266.

${ }^{99}$ Cilliers, J \& Sturman, K. "Challenges facing the AU's Peace and Security Council”. African Security Review 13/1. 2004. 97.

${ }^{100}$ African Union. "Constitutive Act of the African Union". <http://www.au.int/en/sites/default/files/Constitutive_Act_en_0.htm> Accessed on 20 November 2013.

${ }^{101}$ Ibid.

${ }^{102}$ Assembly of the African Union, First Ordinary Session. "Protocol relating to the establishment of the Peace and Security Council of the African Union”. 9 July 2002. <http://www.au.int/en/sites/default/files/Protocol_peace_and_security.pdf > Accessed on 20 November 2013.

${ }^{103}$ Levitt op. cit., p. 110. 
${ }^{104}$ Cilliers \& Sturman op. cit., p. 97.

105 Assembly of the African Union op. cit., Article 2(1).

${ }^{106}$ Ibid., Article 22.

107 African Union op. cit.

${ }^{108}$ Levitt op. cit., p. 116.

${ }^{109}$ Assembly of the African Union op.cit. Article 3(a).

${ }^{110}$ Ibid.

${ }^{111}$ Ibid., Article 3(b).

112 Ibid., Article 3(c).

113 Ibid., Article 3(d).

${ }^{114}$ Ibid., Article 3(e).

${ }^{115}$ Ibid., Article 3(f).

${ }^{116}$ Levitt op. cit., p. 116.

${ }^{117}$ Assembly of the African Union op. cit., Article 5(1).

${ }^{118}$ Ibid., Article 5(1)-(2).

${ }^{119}$ Ibid., Article 5(2) (d)-(e).

${ }^{120}$ IGAD. "Protocol on the establishment of a conflict early warning and response mechanism for the Inter-Governmental Authority on Development (IGAD) Member States". 9 January 2002. <http://cewarn.org/attachments/article/58/The\%20CEWARN\%20Protocol.p df $>$ Accessed on 12 February 2014.

${ }^{121}$ Assembly of the African Union op. cit., Article 7.

${ }^{122}$ Levitt op. cit., p. 120.

123 Assembly of the African Union op. cit., Article 11(1), (3), (4).

${ }^{124}$ Ibid., Article 11(2).

125 African Union Peace and Security Council. "The Panel of the Wise". <http://www.peaceau.org/en/page/29-panel-of-the-wise-pow > Accessed on 12 February 2014.

${ }^{126}$ Assembly of the African Union op. cit., Article 12(5)-(6).

${ }^{127}$ Ibid., Article 12(2)(a).

${ }^{128}$ African Union Peace and Security Council. "The Continental Early Warning System (CEWS)". < http://www.peaceau.org/en/page/28-continental-earlywarning-system-cews > Accessed on 12 February 2014.

129 Tiruneh, BT. "Establishing an early warning system in the African peace and security architecture: Challenges and prospects". KAIPTC Occasional Paper No 29. September 2010. < http://www.kaiptc.org/Publications/OccasionalPapers/Documents/Occasional-Paper-29-Birikit.aspx > Accessed on 5 January 2014, 3 .

${ }^{130}$ Levitt op. cit., p. 121.

${ }^{131}$ Solomon, H. "Critical reflections of the Africa Standby Force: The case of its SADC contingent". Southern African Peace and Security Studies 1/2. 2012. 21.

${ }^{132}$ Cilliers, J. "The African Standby Force: An update on progress". ISS Paper 160. Pretoria: Institute for Security Studies, March 2008, 1. 


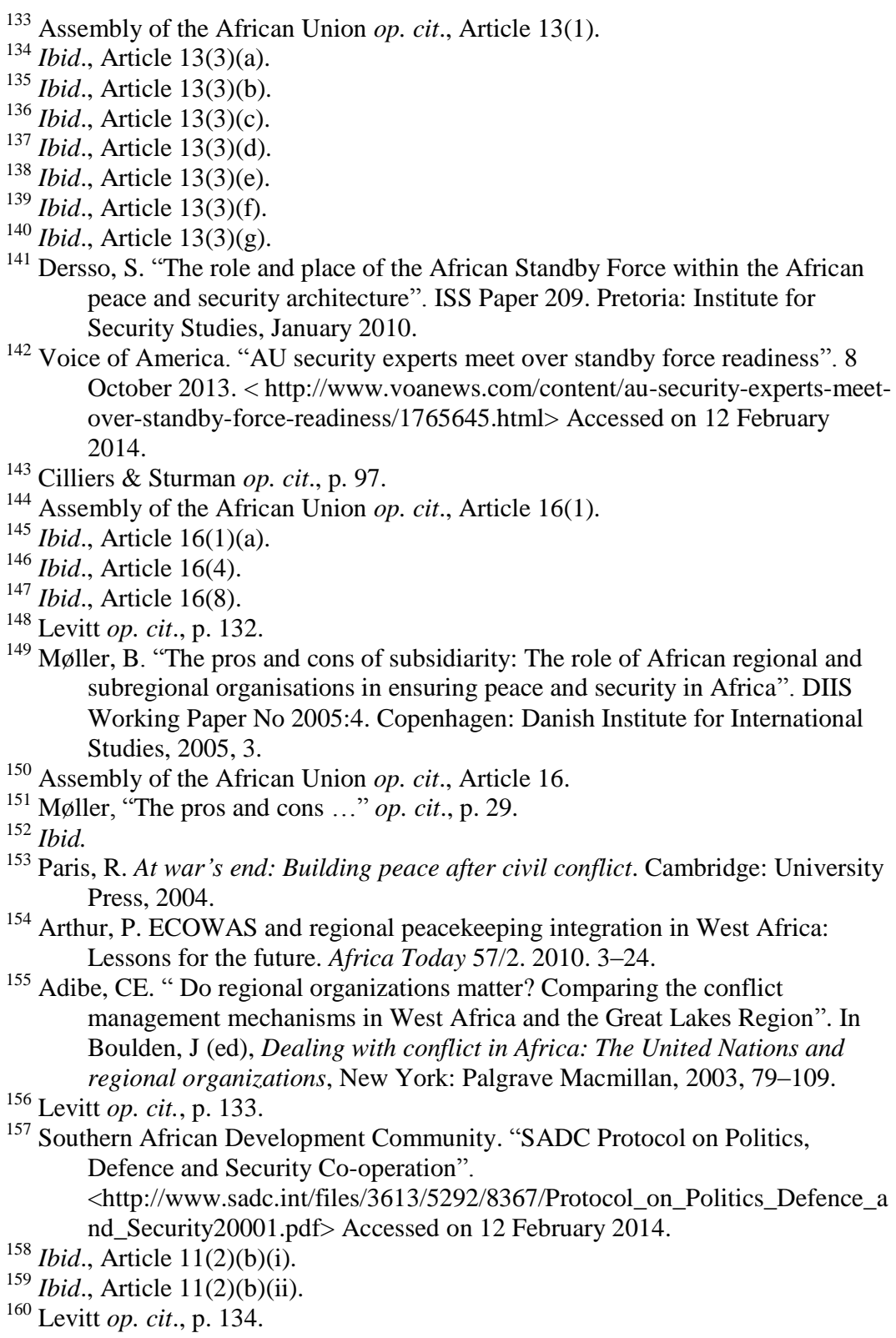


${ }^{161}$ Powell op. cit., p. 19.

162 Aning op. cit., p. 11.

${ }^{163}$ Ekiyor, T. "The role of civil society in conflict prevention: West African experiences". Disarmament Forum 4. 2008. 29.

${ }^{164}$ Ibid., p. 32.

165 Aning op. cit., p. 10. 